\title{
Determinants of School Choice: Evidence from Rural Punjab, Pakistan
}

\author{
Hamna Ahmed ${ }^{*}$ and Sahar Amjad Sheikh ${ }^{* *}$
}

\begin{abstract}
The objective of this study is to understand why parents in rural areas of Punjab, Pakistan, choose to send their children to private schools when free public schools are available. The study utilizes the Privatization in Education Research Initiative (PERI) school choice dataset compiled by the Lahore School of Economics in collaboration with the Punjab Bureau of Statistics. These data provide rich information on parents' perception of their child's school relative to alternative schools he or she could have attended. The findings suggest that parents' perceptions play an important role in school choice. In particular, their perceptions of school quality and employment opportunities emerge as key determinants of private school choice. Additionally, expenditure on and access to private schooling relative to public schooling as well as the socioeconomic status of the household have a significant impact on parents' probability of choosing a private school for their child.
\end{abstract}

Keywords: School choice, public vs private, rural Punjab, Pakistan.

JEL classification: A19, H13, R20.

\section{Introduction and Motivation}

Pakistan has pledged to achieve "education for all" such that all children (particularly girls) have access to free and good-quality primary schooling in line with the Millennium Development Goal of universal primary education by 2015. In the wake of such international initiatives, the country has made some progress in education indicators over the past decade: the gross enrollment rate at the primary, secondary, and tertiary levels increased by 15, 6.3, and 3.9 percent between 2001 and 2009. Nonetheless, the country still ranks lowest in terms of education indicators relative to its South Asian comparators (Table A1 in the Appendix). Thus, it

\footnotetext{
* Assistant Professor, Lahore School of Economics, Lahore, Pakistan.

** Teaching Fellow, Lahore University of Management Sciences, Lahore, Pakistan.
} 
is likely Pakistan will miss the deadline for meeting the goals of education for all and universal primary education by 2015.

In 2010, under Article 25-A of the 18th Amendment to the Constitution, access to free and compulsory education was declared a fundamental right for all children between the ages of 5 and 16 years. But with public expenditure on education declining instead of increasing (from 2.2 percent of GDP in 2005/06 to 2 percent in 2009/10), the current bleak status of education in Pakistan indicates that guaranteeing this right remains a formidable challenge (Pakistan, Ministry of Finance, 2010).

In recent years, many developing countries have seen a surge in low-fee private schooling (LFP). De, Majumdar, Noronha, and Samson (2002), Kingdon (2007), and Srivastava (2006) find support for increasing trends in LFP schooling in India. Nearly 30 percent of the rural populace in India "can access a fee-charging primary private school in the same village" (Muralidharan \& Kremer, 2006). Srivastava (2007) notes that, although the state of Uttar Pradesh is educationally backward, it has a private school enrolment rate of 57.6 percent-the second highest in the country. The rise of private schooling has also been witnessed in Bolivia where nearly one fifth of all students at the primary and secondary levels are enrolled in private schools (Psacharopoulos, Arieira, \& Mattson, 1997). Pakistan has undergone similar trends: in 2010/11, 25 percent of all schoolgoing children were enrolled in private schools (Pakistan Bureau of Statistics, 2011). To consider these trends in a global context, the private enrollment rate in developed countries is generally low; for example, private school enrollment in OECD countries stands at 3 percent due to substantial public investment in education (Checchi et al., 2004).

The rise in private schooling has stirred a debate on the merits and possible demerits of this expansion. On the positive side, the private sector offers a cost-effective means of providing education, ${ }^{1}$ thereby filling the void created by the inadequate supply (both in terms of quality and quantity) of public education services (Tooley, 2004; Tooley \& Dixon, 2006; Tooley, Dixon, \& Gomathi, 2007). On the other hand, critics of private sector expansion emphasize that the provision of education is one of the core responsibilities of the government; they have also raised concerns about equity (Lewin, 2007; Rose, 2009). Since private schooling entails greater expenditure relative to public schooling, there are doubts about the

\footnotetext{
${ }^{1}$ According to Andrabi, Das, Khwaja, Vishnawath, and Zajonc (2007), "educating a child in a public school costs society twice as much as it costs to educate the child in a rural private school" (PRs 2,000 a year in a public school compared to PRs 1,000 a year in a private school).
} 
extent to which the private sector can include the poorest in the economic growth cycle.

In the context of Pakistan, however, with shrinking education budgets and weak commitment to education reforms, the private sector has emerged as an important provider of education services for the rural poor (Andrabi et al., 2007; Alderman, Orazem, \& Paterno, 2001)² with 15 percent of all school-going children in the bottom 20 percent of the population attending private schools in rural Pakistan (Pakistan Bureau of Statistics, 2009, Table A2). Against this backdrop, our objective is to assess why parents choose LFP schools for their children when free public schools are available.

The main emphasis in answering this question will be on the behavioral aspect of the decision-making process, i.e., on the role of parents' perceptions in shaping school choice, while controlling for a range of child- and household-specific attributes. Thus, we use parents' perceived indicators regarding their child's teacher, school infrastructure, etc., rather than actual measures (for instance, parents' assessment of teachers' competence levels rather than actual teacher performance), Notions of school and teacher quality and of child capability form an important basis for defining the value of education in parents' eyes and in choosing a school for their child. Identifying and analyzing the factors that give private schools a comparative edge over public schools will be useful for policies aimed at improving quality in both public and private schools.

The scope of this study is limited to Punjab. Of the four provinces, Punjab has been chosen on two accounts: First, it is the largest province in terms of population and the second largest in terms of area. Second, and more importantly, the spread of private schooling has been largest in Punjab compared to the other provinces. Almost a fourth of all school-going children in the 5-18-year age bracket are enrolled in private schools in Punjab compared to a fifth in KP and a twentieth in Sindh and Balochistan.

The growth of LFP schooling has meant an increased menu of education options for the average rural household in Punjab. Approximately 50 percent of households in rural Punjab have access to an

${ }^{2}$ At the primary level, one third of total enrollment is in private schools (Andrabi et al., 2007). While the study finds that private schools are geographically clustered around main settlements and that families residing in central areas of the settlement are wealthier than those at the periphery, children from all socioeconomic backgrounds attend private schools. Alderman et al. (2001) show that, in Lahore, families earning less than USD 1 per capita were sending nearly 50 percent of their children to private schools. 
average of seven to eight schools in the same village (Andrabi et al., 2007). This wider spectrum of options has meant that school choice behavior cannot be analyzed in isolation-it must be done in conjunction with the competing alternatives available to a household.

Bearing this in mind, the data collection as well as the methodology we have employed to assess the determinants of school choice were specially designed to account for the active nature of the marketplace for education in rural Punjab. Thus, information on parents' perceptions of their child's school was collected relative to the alternatives they faced. This "relative" feature of the dataset and methodology distinguishes the study from others on the topic. A second feature of the study is that it extends the analysis of school choice behavior beyond the primary level to include middle- as well as highschool-going children ${ }^{3}$. Prior research on school choice in Pakistan is confined largely to the primary level ${ }^{4}$ (see Andrabi et al., 2007). Parents' expectations from educational investment in their children may differ across schooling levels and it is therefore important to disaggregate the discussion on school choice by levels of schooling.

The literature finds that, on the supply side, school quality emerges as the single most important determinant dictating which school parents will choose for their children. There are various dimensions of "school quality," the most obvious being test scores that gauge student learning levels. Rehman, Khan, Tariq, and Tasleem (2010) point out that parents select private schools because they produce better examination results and engage in activity-based learning. Andrabi et al. (2007) find that there is a huge learning gap between private and public schools: private schoolgoing children tend to outperform public school children in the same village, thus explaining parents' preference for private over public schools ${ }^{5}$.

Apart from test scores, there are other tangible characteristics that relate to school quality, such as physical infrastructure (the condition of the school building, availability of latrines) and student-teacher ratios. Lloyd, Mete, and Sathar (2005) point out that private schools have more teachers

\footnotetext{
${ }^{3}$ Classes 6 to 8 are classified as middle school while classes 9 and 10 are classified as high school.

${ }^{4}$ An interesting dissertation undertaken recently by Khan (2011) looks at school choice behavior between public schools and madrassas (seminaries) in Balochistan. The author has collected data on parents' perceptions of public primary schools and religious schools, teachers' perceptions of these schools, and local officials' perceptions of the quality and performance of both types of schools. The results of this study are forthcoming.

${ }^{5}$ According to one estimate, "Children in public schools will take 1.5-2.5 years to catch up to private school children in grade 3” (Andrabi et al., 2007).
} 
and smaller classes, which reduces the teaching load for a given teacher. Not only do they have lower pupil-teacher ratios, but they also usually have parent-teacher associations to encourage parents' participation in their child's progress. Siddiqui (2007) finds that meting out physical punishment is extremely common in public schools, which could explain why children drop out at an early stage and why parents prefer private schools to the former. All these factors constitute "school quality" and may induce the child to continue his/her education at a private school.

On the demand side, household attributes such as family income (or wealth) and parents' education are important determinants of private school choice (Andrabi, Das, \& Khwaja, 2008; Iram et al., 2008; Lloyd et al., 2005; Alderman et al., 2001; Burney \& Irfan, 1995; Sathar \& Lloyd, 1994). Apart from the miscellaneous expenditure incurred on uniforms, books, and transportation, and the opportunity cost of not having the child to help in household chores, private schooling entails additional costs in the form of tuition fees. Consequently, the lower the family income, the less the family's ability to bear the costs associated with private schooling and the greater the likelihood that the child will either not be enrolled or will be enrolled in a public, rather than a private, school. Educated parents have a better chance of assessing the quality of their child's school (Andrabi, Das, \& Khwaja, 2002). Thus, one would expect better-educated parents to send their children to private schools and not public schools if they perceive the former to be of a higher quality.

In addition, the distance to school is found to be an important factor in parents' school choice behavior. In a sample of 812 schools in three rural districts of Punjab, 34 percent of children lived at a walking distance of 5 to 15 minutes while 40 percent lived at a walking distance of 5 minutes or less (Andrabi et al., 2007). The study also finds that private schools in rural Pakistan are generally clustered around the main village settlements while public schools are located mostly in the peripheral areas. Given this clustering of private and public schools in the education market, it is a natural response for "distance-conscious" parents to choose nearby private schools rather than far-away public schools.

The rest of the study is organized as follows: Section 2 provides a theoretical framework, Section 3 presents some basic descriptive data, and Section 4 describes our research methodology. Section 5 presents the results and discusses the main findings of the study along with their policy implications and Section 6 concludes the study. 


\section{Theoretical Framework}

The study assumes a two-period model, given the dynamic nature of parents' decision-making, i.e., their decision of how much to invest in their children today will be shaped by the future labor market returns they expect on this investment. In the first period, parents invest in their child's schooling; in the second, the child has become an adult and started working in the labor market. Household utility is expected to be a function of consumption in each period.

Consumption in the first period (when parents are investing in their children) will be a function of (i) market income (earned by the household head or by other working members of the family) and (ii) nonmarket income (public or private transfers such as stipend programs run by the government, a family bequest, etc.) net of schooling costs.

Schooling costs entail both direct and indirect/opportunity costs. Direct schooling costs are expected to be a function of factors such as school fees, distance from the school and the mode of transportation used, and the child's gender. For instance, parents may incur higher costs if their child's school is far from home. Similarly, they may opt for different modes of transportation for boys and girls. Due to safety concerns, walking to school may be a less common practice for girls than for boys. This, in turn, would imply differing levels of transportation expenditure as part of the overall cost of schooling. Indirect schooling costs entail the opportunity cost of the child's time spent in school-time that could alternatively be spent contributing to household chores, helping on the farm or with a family enterprise, or even supplementing household income by working in the labor market.

On the other hand, the perceived benefits of the child's schooling will depend on parents' perceived knowledge of the employment opportunities available to the child, their perception of the child's school quality, and their aspirations for the child. For instance, if parents believe that adequate employment opportunities exist for their children, they may be willing to invest more in the latter's schooling since its perceived benefits are higher than for those parents who do not perceive adequate employment opportunities for their children in the labor market.

Consumption in the second period will be a function of (i) income earned by parents, (ii) unearned income, if any (such as transfer payments), and (iii) the child's labor market returns (who is an adult by period 2). These 
returns will depend on how much the child learnt during his or her school years. Learning outcomes, in turn, will be a function of the duration for which the child stays in school, the quality of the school, and the amount of educational inputs provided by the parents (school supplies such as books, educational toys, the time spent by parents with the child, which has pedagogic value, etc.).

Based on this theoretical framework, we can see that parents' perceptions are an important factor in determining how much schoolrelated expenditure they are willing to incur. A comparison of this cost with the expected future benefit (in the form of the child's income as an adult) is instrumental in determining parents' school choice for their child.

\section{Data}

This section describes the dataset used in this study and provides some descriptive statistics.

\subsection{Data Source and Sample}

The study is based on primary data collected as part of the Privatization in Education Research Initiative (PERI) by the Lahore School of Economics in collaboration with the Punjab Bureau of Statistics. The sample consists of 1,024 households that were visited twice-once in 2007 as part of the Multiple Indicator Cluster Survey, and subsequently in April 2011 for a second round of data collection. The survey was conducted across 64 clusters in eight tehsils of rural Punjab, spanning the northern, central, and southern regions. ${ }^{6}$ The number of tehsils in each region was randomly selected according to the proportionate sampling approach. Our analysis uses the cross-sectional data collected in the second round.

Of a sample of 2,078 children between 5 and 18 years of age, 68 percent were enrolled in school, 17 percent had never attended school, and 15 percent had attended school in the past. Children under 5 were dropped because the average school-starting age in the country ranges between 5 and 6 years. Similarly, while one would normally expect children to finish high school (grade 10) by 15 or 16, the upper threshold of 18 was chosen in order to account for grade repetitions and late entry into school, which happens quite frequently.

\footnotetext{
6 Western Punjab was excluded because high attrition rates were expected due to the large-scale infrastructure damage caused by the floods of 2010.
} 
The sample was further restricted to (i) children enrolled in private or public schools 7 at the primary, secondary, or high level and (ii) those who had the "choice" of being sent to a private school. For the purpose of our investigation, "choice" is defined as affirmative if there was at least one child going to a private school in that cluster. ${ }^{8}$ This leaves us with a working sample of 943 children. Of these, 30 percent are enrolled in private schools and the rest in government schools.

\subsection{Descriptive Statistics}

\subsubsection{Quality}

We quantify the quality of public and private schools along three dimensions: infrastructure quality, academic quality, and teacher quality. Figure 1 shows the average parental perception of the quality of infrastructure, teachers, and specialized subject teaching across private and public schools as measured by aggregated indices for each dimension. The indices range between 0 and 10 with a higher value denoting higher perceived quality along that dimension (details of how these indices were constructed are given in the next section).

A comparison of parents' perception of the average quality of private relative to public schools shows that parents perceive private schools to be superior to public schools. That is, parents consider private schools to have better infrastructure, more competent teachers, and a higher standard of subject teaching in disciplines such as mathematics, English, and science (Figure 1).

Figure 1: Parents' perception of the quality of private and public schools

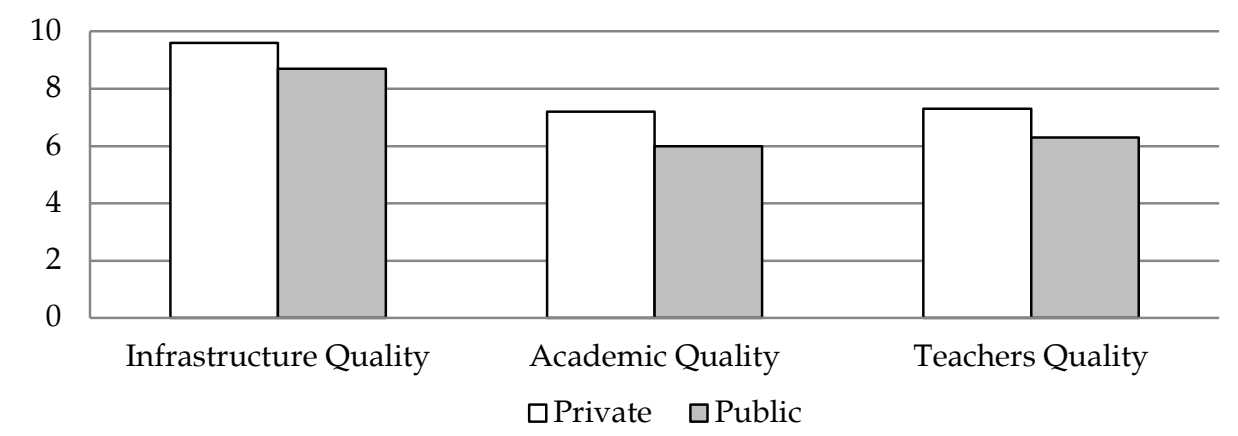

\footnotetext{
${ }^{7} 33$ children going to schools other than private or public, such as community schools, foundationassisted schools, and madrassas, were excluded from the sample.

${ }^{8} 11$ clusters were dropped from the analysis because of the absence of an alternative school choice.
} 


\subsubsection{Employment Opportunities}

The raw data reveals that parents perceive different jobs for their sons and daughters (Figure 2): 53 percent of female children are perceived to gain employment as a teacher as opposed to only 5 percent of the male sample. On the contrary, the percent of male children perceived to work in the government sector is about twice as high as that of females.

Figure 2: Parents' perception of employment opportunities by gender (percent of children)

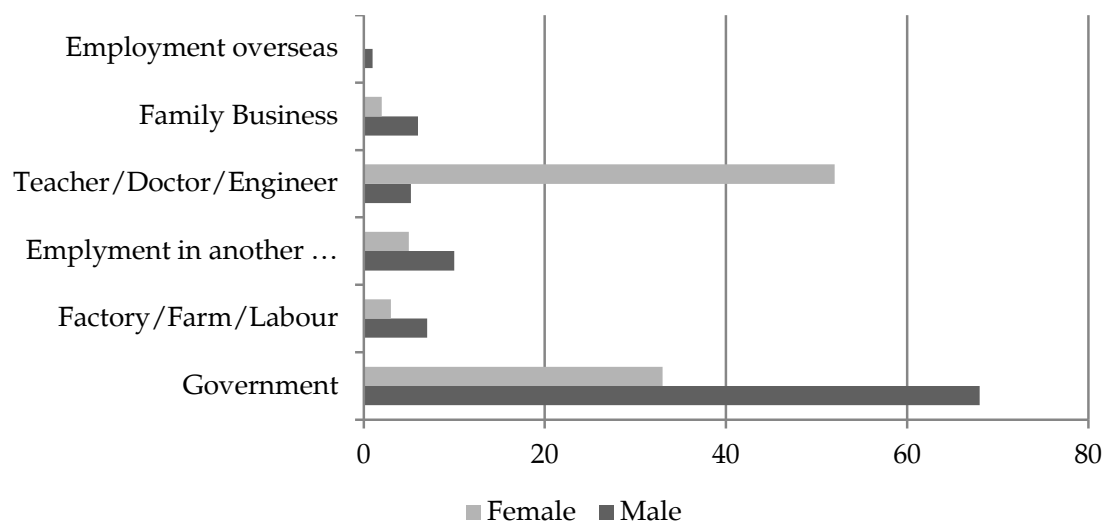

\subsubsection{Cost of Schooling}

The overall sample of school-going children was disaggregated into sub-samples of children attending private and public schools. Computing the average monthly tuition fee for the two sub-samples shows that there is a significant wedge between private and public schooling costs, the former being much higher than the latter. More precisely, the average monthly tuition fee for private school-going children is PRs 288 while that for public school-going children is PRs 15.

\subsubsection{Wealth}

Based on the raw data, three main observations can be made with regard to wealth, gender, and private school enrollment. First, private schools cater to the rural poor in Punjab. Enrollment rates by wealth quintile show that 9 percent of all school-going children in the bottom 20 percent of the population are enrolled in private schools (Table 1). Second, wealthier parents are more likely to send their children to private schools than poor parents. The share of private school-going children increases 
with socioeconomic status, the share in the top 20 percent being four times the share in the bottom quintile (Table 1). Third, parents from all wealth backgrounds prefer to send their daughters to private rather than public schools. The literature documents a strong male bias in the enrollment decision (Aslam \& Kingdon, 2008), but there appears to be a pro-female bias in the private versus public school decision. This is evident from the fact that a higher percent of females are enrolled in private schools than males across all wealth quintiles (Table A2 in the Appendix).

\section{Table 1: Patterns of enrollment and out-of-school children (5-18) by socioeconomic status ${ }^{9}(\%)$}

\begin{tabular}{lccccccc}
\hline & \multicolumn{2}{c}{ In school $^{*}$} & \multicolumn{2}{c}{ Out of school $^{*}$} & \multicolumn{4}{c}{ Type of school** } \\
\cline { 2 - 8 } Quintile & Enrolled & Never attended & Dropouts & Private & Govt. & Madrassa & Other \\
\hline Lowest & 50.8 & 37.5 & 11.7 & 9.2 & 86.5 & 0.0 & 4.3 \\
Second & 68.5 & 14.4 & 17.1 & 14.9 & 80.6 & 0.5 & 4.0 \\
Third & 65.8 & 18.7 & 15.5 & 32.2 & 66.8 & 0.0 & 1.0 \\
Fourth & 69.2 & 9.9 & 20.9 & 28.6 & 65.2 & 0.0 & 6.2 \\
Highest & 79.4 & 6.3 & 14.3 & 44.1 & 53.4 & 1.0 & 1.6 \\
\hline
\end{tabular}

Note: ${ }^{*}=\%$ of children, ${ }^{* *}=\%$ of enrolled children.

Source: PERI School Choice Survey, 2011.

\subsubsection{Access}

In the overall sample, the average time it takes to reach school is approximately 15 minutes. Moreover, 82 percent of the children were reported to walk to school.

\section{Methodology}

\subsection{Quality and School Choice}

In order to understand why parents choose private over public schools in rural Pakistan, the study specifies the following probability choice model:

$\operatorname{Prob}\left(S_{i k}=1 \mid P S, X\right)=\gamma+\sum_{n=1}^{4} \beta_{n}\left(P S_{i k n}{ }^{p}-P S_{i k n}{ }^{g}\right)+\beta X+\varepsilon_{i k}$

\footnotetext{
${ }^{9}$ Socioeconomic status refers to the level of aggregated wealth owned by the household as given by the wealth index, which is based on ownership of consumer durables, condition of housing, and access to basic utilities and amenities. For more detail, see Section 4.1.
} 
where $S$ is a dummy variable that is equal to 1 if child $i$ of parents $k$ is enrolled in a private school and 0 if enrolled in a public school. The variable of interest is: $\left(P S_{i k}\right)$ i.e., parent $k^{\prime}$ s perception of the quality of school that child $i$ attends. The superscript $p$ refers to private while $g$ refers to public (or government) schools. Perceptions of school quality are quantified along $n$ various dimensions, which include the quality of (i) subject teaching, (ii) child i's class teacher, and (iii) the school's infrastructure. For each of these dimensions, an index has been constructed using principal component analysis (PCA).

The index for perceptions of infrastructure quality is based on five measures: (i) parents' observation of the condition of the school building as well as their knowledge of whether the school has (ii) a boundary wall, (iii) a functional latrine, (iv) electricity, and (v) water. The index for perceptions of subject quality is based on parents' rating of mathematics teaching, English teaching, and science teaching in their child's school. The index for perceptions of teacher quality captures three dimensions: (i) parents' knowledge of the teacher's educational qualifications, (ii) their opinion of the teacher's regularity, and (iii) their rating of the teacher's teaching skills.

Perceptions of subject teaching quality and teachers' teaching quality are distinct and thus it is important to incorporate these two variables separately. The main reason is that the perceptions-based teacher quality index is based on parental perception of the class teacher's educational qualifications, teacher absenteeism, and teaching ability. The subject teaching quality index is based on how parents rate the quality of English, mathematics, and science teaching in the child's school. At the primary level, one might expect the class teacher to be responsible for teaching all subjects, but at the middle and high levels, children tend to have separate teachers for each subject. Given this, we feel it is important to include both variables in the regression. The correlation between the two indices is equal to approximately 33 percent, which is classified as moderate. Moreover, the results in Table 2 for the middle- and high schoolgoing age group also provide evidence to support the claim that both indices are likely to capture distinct dimensions. To make all these indices comparable, they are rescaled to lie between 0 and 10 .

Since the objective is to study the attractiveness of private schools relative to public schools, the variable of interest $(P S)$ takes a differenced form in order to account for this relativity. Thus if child $i$ is enrolled in a private school, the counterfactual is given by $\left(P S_{i k n}{ }^{g}\right)$ and represents the mean 
perception of all parents in that tehsil 10 regarding the quality of the public schools in which their children are enrolled. Similarly, if child $i$ is enrolled in a public school, the counterfactual is given by $\left(P S_{i k n}{ }^{p}\right)$ and represents the average perception of parents whose children are enrolled in private schools in that particular tehsil. Assuming a particular child $i$ in household $k$ who currently attends a private school, the best counterfactual would be parental perception had the same child $i$ attended an alternative type of school (public, in this case) before he or she started school.

Observing parents' perceptions of both sectors before child $i$ was enrolled in school would have ensured that we captured parental perceptions at the time the choice of school was made. Unfortunately, this counterfactual is unobservable. One alternative to quantifying household $k^{\prime} \mathrm{s}$ perception of the public and private sectors would have been to look at households in which siblings attended schools in both sectors. The underlying idea is that, if child $i$ attends a private school while his sibling, child $j$, attends a public school, we could use the parental perception of child $j$ 's school to serve as a counterfactual for the parental perception of child $i$ 's current school. Unfortunately, there were very few households in which this was the case. As a result, we resorted to using the average parental perception of the alternative type of school in the tehsil in which child $i$ resides as a counterfactual for parental perception of child $i$ 's current school.

On the second issue of the time at which parental perceptions were recorded, the age group we were interested in studying comprised children between 5 and 18 years in order to undertake a detailed analysis across all levels of schooling. Given our study sample, trying to record parental perception of the quality of both sectors before the child was enrolled would have meant significant recall bias on the part of the parents. For instance, their school-choice decision for a 15-year-old currently going to high school would have been made long ago. Asking for parental perceptions at the time the child was enrolled would have resulted in a lot of noise in the data. Thus, while we recognize the limitation of this variable in not being able to capture perceptions ex-ante to the school-choice decision, we feel it was the best available option given the considerations outlined above.

$X$ is a vector of child-, parent-, and household-specific controls. This includes child $i$ 's gender, access to school, mother and father's level of

10 An administrative sub-unit of a district. Another possibility would have been to use cluster-specific means. However, since our variable of interest, parental perception, takes a differenced form, and given the small geographic size of a cluster, using cluster-means might not have allowed for greater variation in the independent variables. Thus, tehsil-specific means are employed for all perception variables. 
education, household size, total number of children of school-going age in the household, the household's socioeconomic status, and its regional location. Child gender is measured by a dummy variable that is equal to 1 if child $i$ is male and 0 if child $i$ is female. Parental education (of both mother and father) is measured by completed years of schooling.

As with the school-quality variables, access to school (measured by the time taken to reach school) also takes a differenced form to account for the nature of the dependent variable (i.e., the choice of private school relative to public school). Thus, if child $i$ is enrolled in a private (public) school, the access variable will be the difference between the time it takes for child $i$ to travel to school and the average time it takes to travel to a public (private) school in that particular cluster. To capture the differential penalty of distance on school choice with respect to gender, we augment the specification by adding a distance-gender interaction term.

Both household size and the total number of children of schoolgoing age capture the degree of competition for intra-household resources. The former illustrates the overall burden on household resources ${ }^{11}$ while the latter demonstrates the extent of the resource constraint with regard to education-related expenditure allocations within the household.

Household socioeconomic status is captured by a categorical variable that ranges from 1 to 5 where 1 stands for the bottom quintile (the bottom 20 percent of the population) while 5 stands for the top quintile (the top 20 percent of the population). These quintiles are based on each household's wealth index, constructed using PCA. Its constituent variables are: rooms per capita; the material used to construct the walls, roof, and floor of the dwelling; the availability of electricity and gas; type of cooking fuel used; and ownership of consumer durables (radio, television, cable television, telephone, mobile telephone, computer, Internet access, refrigerator, air conditioner, washing machine/dryer, air-cooler/fan, cooking range/microwave, sewing machine, iron, water filter, watch, bicycle, motorcycle, car, animal-drawn cart). The wealth index is also rescaled to lie between 0 and 10 .

For the purpose of capturing regional variation in school choice in rural Punjab, the location of the household is determined by two dummy variables, "north" and "south," with "central" as the base category. These

11 The model was also run with a dependency ratio in place of household size: there were no significant changes in the results. 
classifications have been made according to the criteria given in Cheema, Khalid, and Patnam (2008). The dummy variables take on a value of 1 if child $i$ belongs to a household located in northern or southern Punjab, and 0 otherwise.

$$
\begin{gathered}
\operatorname{Prob}\left(S_{i k}=1 \mid I_{-} Q, T_{-} Q, X\right)=\gamma+\beta_{1} \text { Infrastructure }_{-} \text {Quality } \\
\beta_{2 C} \text { Teacher_Quality }_{U C}+\beta X+\varepsilon_{i k}
\end{gathered}
$$

As a next step, we employ specification (2) and use factual data on school quality. This data comes from the Annual School Census (2007/08) undertaken as part of the Punjab Education Sector Reforms Package. School quality is measured by two indices: (i) infrastructure quality and (ii) teacher quality. The former index measures the average quality of infrastructure in public schools in each union council. The index has been constructed using PCA and incorporates various dimensions such as (i) whether the school is located in a building, (ii) the condition of the school building, (iii) the construction material used, (iv) whether the school has a boundary wall, (v) whether the school has a gate, (vi) whether the school has a sewerage system, and (vii) access to basic utilities such as water, electricity, and a toilet.

Similar to the infrastructure index, the teacher quality index measures the average quality of teachers in public schools in each union council. The index has also been constructed using PCA and is based on (i) the teacher's academic qualifications, (ii) the teacher's professional qualifications, and (iii) a comparison of the impact of parental perception of school quality with actual school quality. This will help determine the extent to which perceptions reflect reality.

\subsection{Employment Opportunities and School Choice}

We expect the nature of employment opportunities that parents perceive for their child to play an instrumental role in choosing the child's school. Thus, model (1) is augmented by adding parents' perception of the employment opportunities available to child $i$ in community $c$ :

$$
\begin{gathered}
\operatorname{Prob}\left(S_{i k}=1 \mid P S, E m p, X\right)=\gamma+\sum_{n=1}^{3} \beta_{n}\left(P S_{i k n}^{p}-P S_{i k n}{ }^{g}\right)+ \\
\beta_{5} E m p_{c}+\beta X+\varepsilon_{i k}
\end{gathered}
$$

For the two purposes of estimation, these employment opportunities are classified into broad categories: (i) high-skill jobs, which require quality and specialized education, such teaching, medicine, engineering, or 
government sector employment ${ }^{12}$ (ii) low-skill jobs that might not justify investing in a costly private education, such as farm or factory labor.

Perceptions of employment opportunities are measured by a dummy variable that is equal to 1 if parents perceive low-skill jobs to be prevalent in the community and 0 if they perceive that high-skill jobs are available in the surrounding area. The perceived availability of employment opportunities is likely to have a differential impact on school choice across wealth quintiles. To formally test for this, the specification is augmented by adding an employment ${ }^{*}$ wealth interaction term.

\subsection{Expenditure and School Choice}

As a third step, model (1) is augmented by adding schooling costs as measured by the total expenditure incurred by parents $k$ on child $i$ 's schooling and is given by equation (4). As shown in the theoretical framework, schooling costs are an important dimension of parents' decision making with regard to their child's school: these costs will affect consumption and hence utility in the period over which the parents will invest in their child's education.

As before, the expenditure variable also takes a differenced form to account for the private relative to public school choice dependent variable. Thus, if the child is enrolled in a private school, the schooling cost variable will be the difference between the total monthly expenditure incurred on child $i\left(\operatorname{Exp}_{i k}{ }^{p}\right)$ and the average monthly expenditure incurred on public school going children in the respective cluster ${ }^{13}\left(\operatorname{Exp}_{i k}{ }^{g}\right)$, and vice versa.

$$
\begin{gathered}
\operatorname{Prob}\left(S_{i k}=1 \mid P S, \operatorname{Exp}, X\right)=\gamma+\sum_{n=1}^{4} \beta_{n}\left(P S_{i k n}^{p}-P S_{i k n}{ }^{g}\right)+ \\
\beta_{5}\left(\operatorname{Exp}_{i k}{ }^{p}-\operatorname{Exp}_{i k}{ }^{g}\right)+\beta X+\varepsilon_{i k}
\end{gathered}
$$

For the specifications listed above, our investigation is carried out in two stages. The first stage employs an aggregated approach to acquire a broad overview of the determinants of school choice for the pooled sample comprising all 5-18-year-old private and public school-going children. In the second stage, the analysis is enriched by undertaking two

\footnotetext{
12 In rural areas, public sector jobs are considered very prestigious, and the prospect of government employment may incentivize parents to undertake the high expenditure on their child's schooling.

13 Pakistan comprises of four provinces namely Punjab, Sind, KP and Balochistan. Each province is divided into divisions while each division is sub-divided into districts. Each district is further divided into tehsils/talukas. For purposes of data collection, the Punjab Bureau of Statistics has further divided tehsils into rural and urban clusters.
} 
distinct types of disaggregation: one at the gender level to capture the difference in private school enrollment for males and females, and one at different levels of schooling to gauge how enrollment patterns in private school and the determinants of school choice change across the primary, middle, and high school tiers.

\section{Results and Discussion}

\subsection{Perceptions of Quality and School Choice}

The quality of subject teaching is instrumental in explaining school choice at the middle and high level, but not at the primary level. The subject teaching quality index is seen to be insignificant at the primary level but significant in explaining school choice at higher levels. In particular, the impact of better teaching quality at private schools relative to public schools on private school enrollment is almost twice as strong for high school children (8 percent) relative to middle school children (4 percent) (Table 2, columns 5 and 6). This could be because, at higher levels (compared to the primary level), parents by virtue of undertaking comparatively greater expenditure are more concerned about the quality of knowledge their children acquire at school.

While the quality of subject teaching matters for males, it does not for females. In the male sample, parents with a better perception of the quality of teaching at private schools (relative to public schools) are 5 percent more likely to send their sons to private schools (Table 2, column 2). However, for females this effect is insignificant (Table 2, column 3), ${ }^{14}$ which may be because parents perceive that the benefits gained from educating their children are likely to differ by gender. For example, better academic quality may be deemed important for sons in order to enhance their future income-earning potential while other considerations, such as improved marriage prospects, may apply to daughters. Thus, parents are likely to be less concerned about the quality of subject teaching when choosing a school for their daughters.

These results are in line with Halai's (2011) study on gender awareness in a rural district of Pakistan: Halai finds that both male and female teachers thought mathematics to be a more useful subject for boys than for girls. Mathematical skills were considered important for future

\footnotetext{
14 An initial round of descriptive statistics revealed that parents' mean perception of subject teaching quality for males was significantly higher than for females. A simple t-test further revealed that this difference was statistically significant at 5 percent.
} 
careers that boys might adopt (such as engineering). For girls, the predominant view was that they would become homemakers and that, apart from helping in household expenditure calculations, mathematics would be of little value to them.

Table 2: Determinants of school choice: Overall, by gender, and by schooling level (perceptions data)

\begin{tabular}{|c|c|c|c|c|c|c|}
\hline & $\begin{array}{c}(1) \\
\text { Overall }\end{array}$ & $\begin{array}{c}(2) \\
\text { Males }\end{array}$ & $\begin{array}{c}\text { (3) } \\
\text { Females }\end{array}$ & $\begin{array}{c}(4) \\
\text { Primary }\end{array}$ & $\begin{array}{c}\text { (5) } \\
\text { Middle }\end{array}$ & $\begin{array}{c}\text { (6) } \\
\text { High }\end{array}$ \\
\hline Total children (5-18) & $\begin{array}{l}-0.034^{* *} \\
(0.014)\end{array}$ & $\begin{array}{l}-0.038^{* *} \\
(0.019)\end{array}$ & $\begin{array}{l}-0.033 \\
(0.022)\end{array}$ & $\begin{array}{l}-0.048^{* *} \\
(0.019)\end{array}$ & $\begin{array}{l}-0.047 \\
(0.031)\end{array}$ & $\begin{array}{l}0.048 \\
(0.060)\end{array}$ \\
\hline Household size & $\begin{array}{l}-0.001 \\
(0.007)\end{array}$ & $\begin{array}{l}-0.012 \\
(0.010)\end{array}$ & $\begin{array}{l}0.005 \\
(0.011)\end{array}$ & $\begin{array}{l}-0.009 \\
(0.010)\end{array}$ & $\begin{array}{l}0.013 \\
(0.014)\end{array}$ & $\begin{array}{l}0.003 \\
(0.028)\end{array}$ \\
\hline Socioeconomic status & $\begin{array}{l}0.057^{* * *} \\
(0.016)\end{array}$ & $\begin{array}{l}0.039 * \\
(0.020)\end{array}$ & $\begin{array}{l}0.073^{* * *} \\
(0.026)\end{array}$ & $\begin{array}{l}0.057^{* * *} \\
(0.021)\end{array}$ & $\begin{array}{l}0.003 \\
(0.032)\end{array}$ & $\begin{array}{l}0.199^{* * *} \\
(0.075)\end{array}$ \\
\hline Mother's education & $\begin{array}{l}0.003 \\
(0.007)\end{array}$ & $\begin{array}{l}0.012 \\
(0.009)\end{array}$ & $\begin{array}{l}-0.010 \\
(0.010)\end{array}$ & $\begin{array}{l}0.005 \\
(0.009)\end{array}$ & $\begin{array}{l}0.005 \\
(0.014)\end{array}$ & $\begin{array}{l}-0.029 \\
(0.029)\end{array}$ \\
\hline Father's education & $\begin{array}{l}0.007 \\
(0.005)\end{array}$ & $\begin{array}{l}0.002 \\
(0.006)\end{array}$ & $\begin{array}{l}0.018^{* *} \\
(0.008)\end{array}$ & $\begin{array}{l}0.012^{*} \\
(0.007)\end{array}$ & $\begin{array}{l}0.009 \\
(0.009)\end{array}$ & $\begin{array}{l}0.008 \\
(0.021)\end{array}$ \\
\hline Male & $\begin{array}{l}-0.570^{* * *} \\
(0.131)\end{array}$ & & & $\begin{array}{l}-0.585^{* * *} \\
(0.193)\end{array}$ & $\begin{array}{l}-0.640^{* *} \\
(0.254)\end{array}$ & $\begin{array}{l}-0.922^{* * *} \\
(0.137)\end{array}$ \\
\hline Relative distance & $\begin{array}{l}-0.065^{* * *} \\
(0.022)\end{array}$ & $\begin{array}{l}0.030 \\
(0.019)\end{array}$ & $\begin{array}{l}-0.074^{* * *} \\
(0.026)\end{array}$ & $\begin{array}{l}-0.128^{* * * *} \\
(0.037)\end{array}$ & $\begin{array}{l}-0.081^{*} \\
(0.045)\end{array}$ & $\begin{array}{l}-0.018 \\
(0.072)\end{array}$ \\
\hline Gender*access & $\begin{array}{l}0.101^{* * *} \\
(0.029)\end{array}$ & & & $\begin{array}{l}0.119^{* * *} \\
(0.045)\end{array}$ & $\begin{array}{l}0.104^{*} \\
(0.061)\end{array}$ & $\begin{array}{l}0.156 \\
(0.099)\end{array}$ \\
\hline Subject quality & $\begin{array}{l}0.022^{* *} \\
(0.010)\end{array}$ & $\begin{array}{l}0.046^{* * *} \\
(0.013)\end{array}$ & $\begin{array}{l}-0.016 \\
(0.016)\end{array}$ & $\begin{array}{l}0.006 \\
(0.013)\end{array}$ & $\begin{array}{l}0.038^{* *} \\
(0.019)\end{array}$ & $\begin{array}{l}0.083^{* *} \\
(0.042)\end{array}$ \\
\hline Teacher quality & $\begin{array}{l}0.031^{* *} \\
(0.014)\end{array}$ & $\begin{array}{l}0.024 \\
(0.017)\end{array}$ & $\begin{array}{l}0.035^{*} \\
(0.023)\end{array}$ & $\begin{array}{l}0.022 \\
(0.019)\end{array}$ & $\begin{array}{l}0.031 \\
(0.028)\end{array}$ & $\begin{array}{l}0.084 \\
(0.055)\end{array}$ \\
\hline Infrastructure quality & $\begin{array}{l}0.012 \\
(0.014)\end{array}$ & $\begin{array}{l}0.007 \\
(0.017)\end{array}$ & $\begin{array}{l}0.013 \\
(0.026)\end{array}$ & $\begin{array}{l}-0.005 \\
(0.018)\end{array}$ & $\begin{array}{l}-0.003 \\
(0.039)\end{array}$ & $\begin{array}{l}0.142^{* *} \\
(0.066)\end{array}$ \\
\hline Northern Punjab & $\begin{array}{l}-0.127^{* * * *} \\
(0.044)\end{array}$ & $\begin{array}{l}-0.106^{*} \\
(0.056)\end{array}$ & $\begin{array}{l}-0.158^{* *} \\
(0.069)\end{array}$ & $\begin{array}{l}-0.089 \\
(0.065)\end{array}$ & $\begin{array}{l}-0.038 \\
(0.085)\end{array}$ & $\begin{array}{l}-0.360^{* *} \\
(0.151)\end{array}$ \\
\hline Southern Punjab & $\begin{array}{l}-0.060 \\
(0.055)\end{array}$ & $\begin{array}{l}-0.111^{*} \\
(0.064)\end{array}$ & $\begin{array}{l}0.002 \\
(0.096)\end{array}$ & $\begin{array}{l}-0.027 \\
(0.071)\end{array}$ & $\begin{array}{l}-0.081 \\
(0.105)\end{array}$ & \\
\hline $\mathrm{N}$ & 613 & 337 & 276 & 363 & 145 & 90 \\
\hline
\end{tabular}

Note: Marginal effects reported; standard errors in parentheses; ${ }^{*},{ }^{* *}$, and ${ }^{* * *}$ denote 10,5 , and 1 percent level of significance.

Source: Authors' calculations.

In the pooled sample, perceptions of teacher quality have a significant effect on private school choice. However, the genderdisaggregated results show that teacher quality matters for females but not for males (Table 2, columns 1, 2, and 3). In a companion study, we have disaggregated these indices to study the impact of individual dimensions on school choice. The results help explain why teacher quality matters only 
for females. Moreover, disaggregating the index shows that parents accord varying levels of importance to teaching skills and teacher presence according to the child's level of schooling. Thus, while the aggregated results by level of schooling show no relation to school choice (Table 2, columns 4, 5 and 6), the disaggregated results in the companion study show that teacher presence matters for younger children while teaching skills matter for children in higher classes.

Perceptions of school infrastructure have a significant effect on school choice for high-school children. Parents who perceive the quality of infrastructure of private schools as being better than that of public schools are 14 percent more likely to choose a private school for their child (Table 2, column 6). Compared to primary and middle schools, high schools have greater infrastructure requirements (such as well-equipped science labs). In light of this, perceptions of the quality and condition of high school infrastructure serve as an important predictor of school choice.

High schools also tend to be located farther away than primary or middle schools as they most commonly cater to multiple settlements rather than just one. This can make it difficult for parents to interact regularly with their child's teachers. In the absence of parent-teacher interaction, parents may use their perception of physical infrastructure as a primary indicator of the quality of the high school. This may be why the school infrastructure index emerges as a significant determinant of school choice at the high school level and not at other levels of schooling (Table 2).

\subsection{Actual Quality and School Choice}

Regressions with factual data on teacher quality and infrastructure quality show that teacher quality does not affect parents' school-choice decision. On the other hand, infrastructure quality has a significant impact on parents' school choice for children in the pooled sample. On average, parents living in areas with a higher quality of public school infrastructure have a lower probability of sending their children to private, rather than public, schools. The disaggregated results by gender and level of schooling show that this holds for male children as well as children of primary school age.

A comparison of the results yielded by perceptions data and actual data shows that perceptions of teacher quality matter but actual teacher quality does not. This suggests the presence of large information gaps for parents living in rural areas. For infrastructure quality, both perceptionsbased (for high school children) and fact-based measures matter. This 
suggests that private schooling is not just a demand-side phenomenon driven by perceptions alone but that it is also driven by supply-side characteristics. Parents are more likely to choose private schools in areas where, on average, the quality of public school physical infrastructure is low.

These results could also be driven partly by the nature of the quality dimension we are studying. When dimensions are not tangible (such as a teacher's qualifications and training), perceptions override facts in the decision-making process. When the underlying dimension is explicit and easily observable (such as physical infrastructure), factual information on these characteristics has a more significant influence on school choice.

Table 3: Determinants of school choice: overall, by gender, and by schooling level (actual data)

\begin{tabular}{lllllll}
\hline & $\begin{array}{c}\text { Overall } \\
\mathbf{( 1 )}\end{array}$ & $\begin{array}{c}\text { Males } \\
\mathbf{( 2 )}\end{array}$ & $\begin{array}{c}\text { Females } \\
\mathbf{( 3 )}\end{array}$ & $\begin{array}{l}\text { Primary } \\
\mathbf{( 4 )}\end{array}$ & $\begin{array}{c}\text { Middle } \\
\mathbf{( 5 )}\end{array}$ & $\begin{array}{c}\text { High } \\
\mathbf{( 6 )}\end{array}$ \\
\hline Total children (5-18) & $-0.023^{*}$ & -0.023 & -0.023 & $-0.043^{* *}$ & -0.021 & 0.024 \\
& -0.014 & -0.019 & -0.021 & -0.019 & -0.027 & -0.041 \\
Socioeconomic status & $0.066^{* * *}$ & $0.062^{* * *}$ & $0.074^{* * *}$ & $0.066^{* * *}$ & 0.02 & $0.154^{* * *}$ \\
& -0.013 & -0.017 & -0.022 & -0.017 & -0.028 & -0.047 \\
Mother's education & 0.009 & $0.018^{* *}$ & 0.001 & $0.016^{* *}$ & -0.008 & -0.022 \\
& -0.006 & -0.008 & -0.009 & -0.007 & -0.014 & -0.018 \\
Father's education & 0.007 & 0.002 & 0.011 & $0.010^{*}$ & 0.006 & 0.007 \\
Gender & -0.004 & -0.005 & -0.007 & -0.005 & -0.008 & -0.014 \\
Relative distance & $-0.557^{* * *}$ & & & $-0.547^{* * *}$ & $-0.883^{* * *}$ & -0.131 \\
& -0.118 & & & -0.176 & -0.115 & -0.403 \\
Gender*access & $-0.049^{* *}$ & $0.041^{* *}$ & $-0.051^{* *}$ & $-0.098^{* * *}$ & $-0.111^{* *}$ & $0.134^{* *}$ \\
Teacher quality & -0.02 & -0.017 & -0.022 & -0.032 & -0.045 & -0.063 \\
& $0.097^{* * *}$ & & & $0.110^{* * *}$ & $0.182^{* * *}$ & -0.034 \\
Infrastructure quality & -0.026 & & & -0.038 & -0.058 & -0.076 \\
& 0.036 & 0.038 & 0.032 & 0.05 & -0.136 & 0.135 \\
Northern Punjab & -0.062 & -0.079 & -0.098 & -0.081 & -0.13 & -0.173 \\
& $-0.148^{* *}$ & $-0.157^{*}$ & -0.143 & $-0.160^{*}$ & -0.077 & -0.102 \\
Southern Punjab & -0.046 & -0.094 & -0.114 & -0.09 & -0.158 & -0.229 \\
& -0.048 & -0.06 & -0.028 & -0.002 & -0.006 & $-0.253^{* *}$ \\
N & -0.051 & $-0.123^{* *}$ & -0.076 & -0.069 & -0.097 & -0.104 \\
\hline & -0.048 & -0.053 & -0.083 & -0.025 & -0.042 & $-0.227^{*}$ \\
& 715 & 398 & 317 & 435 & -0.109 & -0.132 \\
\hline
\end{tabular}

Note: Marginal effects reported; standard errors in parentheses; ${ }^{*}{ }^{* *}$, and ${ }^{* * *}$ denote 10, 5, and 1 percent level of significance.

Source: Authors' calculations.

\subsection{Employment Opportunities and School Choice}

Parents are more likely to choose private schools if they think employment opportunities that require a high level of education are 
available to their children (Table 4). Such jobs might entail working as a government employee, a schoolteacher, or a professional (i.e., a doctor, engineer, or banker). All these jobs require a minimum level of education and have strict eligibility criteria. The availability of lucrative employment opportunities can motivate parents to invest more in their children (the choice of private over public schooling is, in some ways, a reflection of that willingness) since such jobs would promise higher future returns on their children's education. A second reason could be that parents consider private education a means of significantly improving their child's potential for procuring sought-after jobs such as in the government sector or a profession.

Parents are less likely to choose private schools for their children if the prevalent job opportunities do not require specialized education. Thus, if parents perceive the availability of jobs such as farm or factory labor, they have a 12 percent lower likelihood of choosing a private school (Table 4). The decision to invest in a child's education seems to be linked to weighing its costs against expected returns. If the expected future returns are low, as is the case for many jobs in this category, parents will be less willing to bear the cost of private education. Moreover, if parents do not think that the quality of education acquired in school will improve the likelihood of availing the prevalent job opportunities, investing in private education may not be considered worthwhile.

Richer parents are more likely to send their children to private schools even when the prevalent job opportunities do not require specialized education. At lower levels of the wealth distribution, households that perceive low-education jobs to be more prevalent are less likely to choose private schools for their children. The effect is reversed for households in the upper tail of the wealth distribution. Despite the perceived availability of low-education jobs, these households continue to have a greater likelihood of choosing private schools for their children. Thus, the impact of perceived availability of employment opportunities on school choice varies by the household's socioeconomic status (Table 4). ${ }^{15}$

\footnotetext{
${ }^{15}$ We have also used factual data on district-level employment. Specification (3) was rerun by replacing perceptions of available employment opportunities in the area with the actual district-level unemployment rate. In order to check the robustness of these results, specification (3) was run a third time using the percentage of industrial units located in the district (measured by the ratio of firms located in the district) divided by the total number of firms in Punjab. This data was taken from the Census of Manufacturing Industries (2005). The results revealed that these variables capturing actual employment opportunities were insignificant determinants of school choice. This might suggest that parents' perceptions are not aligned with the actual job market. However, the results must be viewed with caution due to endogeneity problems with the actual employment measures used in the analysis.
} 
Table 4: Parents' perception of employment opportunities and school choice

\begin{tabular}{|c|c|c|c|c|c|c|}
\hline & \multicolumn{2}{|c|}{ Overall } & \multicolumn{2}{|c|}{ Males } & \multicolumn{2}{|c|}{ Females } \\
\hline & (1) & (2) & (3) & (4) & (5) & (6) \\
\hline \multirow[t]{2}{*}{ Total children (5-18) } & $-0.033^{* *}$ & $-0.032^{* *}$ & $-0.033^{*}$ & $-0.033^{*}$ & -0.030 & -0.026 \\
\hline & $(0.016)$ & $(0.016)$ & $(0.020)$ & $(0.020)$ & $(0.028)$ & $(0.029)$ \\
\hline \multirow[t]{2}{*}{ Household size } & $-0.016^{*}$ & $-0.015^{*}$ & -0.017 & -0.014 & -0.015 & -0.014 \\
\hline & $(0.009)$ & $(0.009)$ & $(0.012)$ & $(0.011)$ & $(0.014)$ & $(0.014)$ \\
\hline \multirow[t]{2}{*}{ Socioeconomic status } & $0.066^{* * *}$ & $0.042^{* *}$ & $0.054^{* *}$ & 0.022 & $0.091^{* * *}$ & $0.083^{* *}$ \\
\hline & $(0.019)$ & $(0.020)$ & $(0.022)$ & $(0.024)$ & $(0.035)$ & $(0.035)$ \\
\hline \multirow[t]{2}{*}{ Mother's education } & -0.005 & -0.006 & 0.003 & 0.002 & -0.018 & -0.018 \\
\hline & $(0.008)$ & $(0.008)$ & $(0.010)$ & $(0.010)$ & $(0.012)$ & $(0.012)$ \\
\hline \multirow[t]{2}{*}{ Father's education } & $0.009^{*}$ & $0.010^{*}$ & 0.003 & 0.004 & $0.021^{* *}$ & $0.022^{* *}$ \\
\hline & $(0.005)$ & $(0.005)$ & $(0.007)$ & $(0.007)$ & $(0.010)$ & $(0.010)$ \\
\hline \multirow[t]{2}{*}{ Gender } & $-0.651^{* * *}$ & $-0.633^{* * *}$ & & & & \\
\hline & $(0.140)$ & $(0.144)$ & & & & \\
\hline \multirow[t]{2}{*}{ Relative distance } & $-0.054^{* *}$ & $-0.048^{* *}$ & $0.046^{* *}$ & $0.046^{* *}$ & $-0.069^{* *}$ & $-0.066^{* *}$ \\
\hline & $(0.024)$ & $(0.023)$ & $(0.021)$ & $(0.021)$ & $(0.030)$ & $(0.030)$ \\
\hline \multirow[t]{2}{*}{ Gender*access } & $0.111^{* * *}$ & $0.105^{* * *}$ & & & & \\
\hline & $(0.032)$ & $(0.032)$ & & & & \\
\hline \multirow[t]{2}{*}{ Subject quality } & $0.031^{* * *}$ & $0.027^{* *}$ & $0.041^{* * *}$ & $0.034^{* *}$ & 0.009 & 0.008 \\
\hline & $(0.011)$ & $(0.011)$ & $(0.014)$ & $(0.013)$ & $(0.020)$ & $(0.021)$ \\
\hline \multirow[t]{2}{*}{ Teacher quality } & $0.035^{* *}$ & $0.035^{* *}$ & $0.032^{*}$ & 0.029 & 0.040 & 0.041 \\
\hline & $(0.016)$ & $(0.016)$ & $(0.018)$ & $(0.018)$ & $(0.032)$ & $(0.032)$ \\
\hline \multirow[t]{2}{*}{ Infrastructure quality } & 0.022 & $0.025^{*}$ & 0.009 & 0.012 & 0.048 & 0.050 \\
\hline & $(0.015)$ & $(0.015)$ & $(0.017)$ & $(0.017)$ & $(0.031)$ & $(0.031)$ \\
\hline \multirow[t]{2}{*}{ Availability of jobs } & $-0.124^{* *}$ & $-0.399^{* * *}$ & $-0.098^{*}$ & $-0.401^{* * *}$ & $-0.201^{* *}$ & $-0.387^{* * *}$ \\
\hline & $(0.051)$ & $(0.058)$ & $(0.058)$ & $(0.082)$ & $(0.098)$ & $(0.099)$ \\
\hline \multirow[t]{2}{*}{ SES*availability of jobs } & & $0.161^{* * *}$ & & $0.152^{* * *}$ & & 0.138 \\
\hline & & $(0.053)$ & & $(0.053)$ & & $(0.147)$ \\
\hline \multirow[t]{2}{*}{ Northern Punjab } & $-0.130^{* * *}$ & $-0.128^{* * *}$ & $-0.120^{* *}$ & $-0.124^{* *}$ & $-0.173^{* *}$ & $-0.164^{*}$ \\
\hline & $(0.048)$ & $(0.047)$ & $(0.058)$ & $(0.054)$ & $(0.083)$ & $(0.084)$ \\
\hline \multirow[t]{2}{*}{ Southern Punjab } & -0.019 & -0.010 & -0.069 & -0.053 & 0.027 & 0.027 \\
\hline & $(0.070)$ & $(0.071)$ & $(0.079)$ & $(0.083)$ & $(0.126)$ & $(0.127)$ \\
\hline $\mathrm{N}$ & 490 & 490 & 292 & 292 & 198 & 198 \\
\hline
\end{tabular}

Note: Marginal effects reported; standard errors in parentheses; ${ }^{*}{ }^{* *}$, and ${ }^{* * *}$ denote 10,5 , and 1 level of significance.

Source: Authors' calculations.

\subsection{Expenditure and School Choice}

School choice for females is elastic to the expenditure incurred on private relative to public education. The regression results show that the cost of educating a child has a significant impact on the choice of school for females. In particular, a unit increase in expenditure on private schooling relative to public schooling decreases the probability of enrollment of females in private school by 13 percent (Table 5, column 3). However, for males, this factor is insignificant in explaining school choice (Table 5, 
column 2). This reveals that the costs incurred on schooling are a key factor in deciding the type of school for girls, but not for boys.

The impact of relative expenditure on school choice differs by the level of schooling, being smallest at the primary tier and largest at the high school tier (Table 5, columns 4 and 6). The effect of expenditure on school choice is twice as great at the high school level (18 percent) than at the primary level (9 percent). A possible reason for this differential impact is that the privatepublic gap in expenditure increases by the level of schooling, thus having a stronger impact at higher levels.

Table 5: Relative schooling expenditure and school choice

\begin{tabular}{lllllll}
\hline & $\begin{array}{c}\text { Overall } \\
\mathbf{( 1 )}\end{array}$ & $\begin{array}{c}\text { Males } \\
\mathbf{( 2 )}\end{array}$ & $\begin{array}{c}\text { Females } \\
\mathbf{( 3 )}\end{array}$ & $\begin{array}{c}\text { Primary } \\
\mathbf{( 4 )}\end{array}$ & $\begin{array}{c}\text { Middle } \\
\mathbf{( 5 )}\end{array}$ & $\begin{array}{c}\text { High } \\
\mathbf{( 6 )}\end{array}$ \\
\hline Total children (5-18) & -0.009 & -0.029 & 0.013 & -0.014 & -0.036 & 0.177 \\
& $(0.017)$ & $(0.022)$ & $(0.027)$ & $(0.023)$ & $(0.034)$ & $(0.141)$ \\
Household size & -0.013 & $-0.020^{*}$ & -0.013 & $-0.031^{* *}$ & 0.008 & -0.024 \\
& $(0.009)$ & $(0.012)$ & $(0.013)$ & $(0.013)$ & $(0.016)$ & $(0.047)$ \\
Socioeconomic status & $0.050^{* * *}$ & $0.040^{*}$ & $0.072^{* *}$ & $0.054^{* *}$ & -0.012 & $0.329^{* *}$ \\
& $(0.019)$ & $(0.024)$ & $(0.032)$ & $(0.024)$ & $(0.037)$ & $(0.160)$ \\
Mother's education & 0.008 & 0.013 & 0.003 & 0.008 & 0.024 & -0.067 \\
Father's education & $(0.008)$ & $(0.012)$ & $(0.013)$ & $(0.011)$ & $(0.018)$ & $(0.047)$ \\
& 0.004 & -0.003 & $0.019^{* *}$ & 0.009 & 0.000 & 0.051 \\
Gender & $(0.006)$ & $(0.008)$ & $(0.009)$ & $(0.008)$ & $(0.010)$ & $(0.040)$ \\
& $-0.585^{* * *}$ & & & $-0.584^{* * *}$ & $-0.776^{* * *}$ & $-0.972^{* * *}$ \\
Relative distance & $(0.153)$ & & & $(0.217)$ & $(0.224)$ & $(0.106)$ \\
& $-0.060^{* *}$ & 0.039 & $-0.056^{*}$ & $-0.110^{* * *}$ & -0.063 & 0.015 \\
Gender*access & $(0.027)$ & $(0.024)$ & $(0.033)$ & $(0.042)$ & $(0.052)$ & $(0.169)$ \\
& $0.107^{* * *}$ & & & $0.119^{* *}$ & $0.170^{* *}$ & 0.140 \\
Subject quality & $(0.036)$ & & & $(0.051)$ & $(0.075)$ & $(0.230)$ \\
& 0.006 & $0.037^{* *}$ & $-0.049^{* *}$ & -0.011 & $0.041^{*}$ & 0.016 \\
Teacher quality & $(0.012)$ & $(0.016)$ & $(0.020)$ & $(0.016)$ & $(0.023)$ & $(0.062)$ \\
& $0.032^{*}$ & 0.025 & $0.054^{*}$ & 0.026 & 0.033 & 0.066 \\
Infrastructure quality & $(0.017)$ & $(0.021)$ & $(0.030)$ & $(0.023)$ & $(0.033)$ & $(0.101)$ \\
& 0.025 & 0.012 & 0.036 & 0.015 & 0.009 & $0.305^{* *}$ \\
Relative expenditure & $(0.017)$ & $(0.019)$ & $(0.035)$ & $(0.021)$ & $(0.042)$ & $(0.155)$ \\
Northern Punjab & -0.041 & -0.015 & $-0.127^{*}$ & $-0.086^{* *}$ & $-0.177^{* *}$ & $-0.183^{* *}$ \\
Southern Punjab & $(0.034)$ & $(0.040)$ & $(0.069)$ & $(0.041)$ & $(0.088)$ & $(0.091)$ \\
N & $-0.092^{*}$ & -0.066 & $-0.146^{*}$ & -0.044 & -0.010 & -0.429 \\
& $(0.054)$ & $(0.074)$ & $(0.078)$ & $(0.079)$ & $(0.103)$ & $(0.278)$ \\
& -0.112 & $-0.214^{* * *}$ & 0.060 & -0.090 & 0.094 & \\
& $(0.069)$ & $(0.070)$ & $(0.139)$ & $(0.095)$ & $(0.189)$ & \\
& 467 & 256 & 211 & 277 & 115 & 68 \\
\hline
\end{tabular}

Note: Marginal effects reported; standard errors in parentheses; ${ }^{*}{ }^{* *}$, and ${ }^{* * *}$ denote 10,5 , and 1 percent level of significance.

Source: Authors' calculations. 


\subsection{Additional Findings}

\subsubsection{Wealth and School Choice}

It is evident from the descriptive statistics presented in Section 3 that, while private schools cater to the rural poor in Pakistan, wealthier parents are more likely to send their children to private schools relative to poorer parents. These findings are substantiated by the regression results. With each successive quintile, the probability of enrolling in a private relative to public school increases by 6 percent (Table 2, column 1).

The results also show that parents from all socioeconomic groups favor females in the private versus public schooling decision, thus reinforcing the findings obtained from the descriptive statistics in Section 3. The gender differential persists even when other factors are controlled for (Table 2, columns 2 and 3). This may point to the limited public schooling options available for girls. Thus, private schools appear to fill an important gap in the market for education. To fully establish this argument, a detailed profiling of government schools by gender in the surveyed areas is needed, which could prove to be a promising area for future research.

Girls from richer households are more likely to go to private schools than those from poorer households. The gender-disaggregated regression shows that the impact of wealth on school choice varies by gender: females in the second quintile have a 7 percent higher chance of being enrolled in a private school relative to their counterparts in the bottom 20 percent of the wealth distribution (Table 2, column 3). Wealthier households tend to have a greater pool of resources, making it easier for parents to bear the expenses associated with private education. Wealthier households may also have a more progressive attitude toward girls' education since the data show that wealth status is highly (and positively) correlated with parental education. ${ }^{16}$ Thus, for the sample under study, wealthier households are also more literate and would be more inclined to invest in girls' education.

The wealth effect on the choice of private schooling is stronger for high school children than for primary school children across all socioeconomic groups (Table 2, columns 4 and 6). The results show that the wealth effect is three times as great for high school children (20 percent) than for primary school children (6 percent). This is not surprising given that private high school education is more expensive than primary or

${ }^{16}$ With father's education, the correlation is 30 percent; with mother's education, it is 38 percent. 
middle school education. For the sample under consideration, the average monthly tuition fee reported is more than double for private high school children (PRs 518) compared to private primary school children (PRs 242). Therefore, as wealth (i.e., the pool of available resources) increases, the impact on private education we see at the higher tier of schooling is far greater than at the primary level.

\subsubsection{Access and School Choice}

Parents show greater preference for private education as the accessibility of private relative to public schools increases in a cluster. The less time it takes to travel to a private school relative to a public school within a cluster, the higher will be the probability of enrolling in a private school (7 percent) (Table 2, column 1).

Parents are very sensitive to the proximity of private relative to public schools when choosing a school for their daughters. The genderdisaggregated results show that, as the relative distance between a private and public school increases in a cluster, parents are 7.5 percent less likely to choose a private school for their daughters (Table 2, column 3). Regressions by level of schooling illustrate that this effect holds at the primary and middle tiers but not for high school girls. The impact is, however, stronger for younger females (13 percent for primary school-going girls and 8 percent for middle school girls) (Table 2, columns 4 and 5).

Parents' choice of private school for their sons is not tied to the proximity of that school relative to a public school in the area. Thus, while distance matters for females, it is insignificant in the case of males. This is evident from the overall male regression as well as from the genderdisaggregated regressions at the primary and middle school tiers (Table 2, columns 2, 4, and 5).

Distance does not influence school choice for males or females at the high school level: a finding that holds for both males and females (Table 2, column 6). A much larger percent of children at this level use some sort of vehicle. Half of all males and one third of all females in our sample used a motorcycle, school van, rickshaw, or public transport. It could either be that high schools are farther away from the main settlement or that parents perceive these modes of transportation to be safer than walking to school, and thus do not consider distance a significant determinant of school choice at this tier. Needless to say, older children are less vulnerable than younger children and parents may feel more comfortable about sending the former to schools farther away. 


\section{Conclusions}

The objective of this study was to understand why parents in rural areas of Punjab, Pakistan, choose to send their children to private schools when free public schools are available. We have utilized the PERI school choice dataset gathered by the Lahore School of Economics in collaboration with the Bureau of Statistics. This dataset is unique in that it provides rich information on parents' perceptions of the school in which their child is enrolled relative to alternative schools in which the child could have studied potentially. Moreover, contrary to most other studies, the dataset makes it possible to extend the school choice analysis beyond the primary level to the middle and high school tiers. Thus, the "relative" feature of the perceptions data, the methodology we employ, and the analysis disaggregated by primary, middle, and high level of schooling distinguish this piece of work from prior studies on the topic.

Our findings suggest that parents' perceptions play an important role in the school-choice decision. In particular, perceptions of school quality and employment opportunities emerge as key determinants of private school choice. In addition, expenditure on and access to private schooling relative to public schooling as well as the socioeconomic status of the household have a significant impact on parents' probability of choosing a private school for their child.

In the context of Pakistan, we can therefore conclude that the school-choice decision is a combination of both demand- and supply-side factors. Moreover, these findings are important in unraveling the factors based on which parents decide which type of school to send their children. 


\section{References}

Alderman, H., Orazem, P. F., \& Paterno, E. M. (2001). School quality, school cost and the public/private school choices of low-income households in Pakistan. Journal of Human Resources, 36(2), 304-326.

Andrabi, T., Das, J., \& Khwaja, A. I. (2002). The rise of private schooling in Pakistan: Catering to the urban elite or educating the rural poor? (Mimeo). Washington, DC: World Bank.

Andrabi, T., Das, J., \& Khwaja, A. I. (2008). A dime a day: The possibilities and limits of private schooling in Pakistan. Comparative Education Review, 52(3), 329-355.

Andrabi, T., Das, J., Khwaja, A. I., Vishwanath, T., \& Zajonc, T. (2007). Learning and education achievements in Punjab schools (LEAPS): Insights to inform the education policy debate. Washington, DC: World Bank.

Aslam, M., \& Kingdon, G. G. (2008). Gender and household education expenditure in Pakistan. Applied Economics, 40(20), 2573-2591.

Burney, N. A., \& Irfan, M. (1995). Determinants of child school enrolment: Evidence from LDCs using choice-theoretic approach. International Journal of Social Economics, 22(1), 24-40.

Cheema, A., Khalid, L., \& Patnam, M. (2008). The geography of poverty: Evidence from the Punjab [Special Edition]. Lahore Journal of Economics, (September), 163-188.

De, A., Majumdar, M., Noronha, C., \& Samson, M. (2002) Private schools and universal elementary education. In R. Govinda (Ed.), India education report: A profile of basic education (pp. 131-150). New Delhi: Oxford University Press.

Halai, A. (2011). Equality or equity? Gender awareness issues in secondary schools in Pakistan. International Journal of Educational Development, 31(1) 44-49.

Iram, N., Hussain, Z., Anwar, S., Hussain, I., \& Akram, W. (2008). Determinants of child school choice in Punjab: Policy implications. European Journal of Scientific Research, 23(2), 285-293. 
Khan, J. (2011, May). School or madrassa: Parents' choice and the failure of state-run education in Pakistan. Paper presented at the annual meeting of the 55 th Annual Conference of the Comparative and International Education Society, Montreal.

Kingdon, G. (2007). The progress of school education in India (Working Paper No. 71). Oxford, UK: Global Poverty Research Group.

Lewin, K. (2007). The limits to growth of nongovernment private schooling in sub-Saharan Africa. In P. Srivastava \& G. Walford (Eds.), Private schooling in less economically developed countries: Asian and African perspectives (pp. 41-65). Oxford, UK: Symposium.

Lloyd, C. B., Mete, C., \& Sathar, Z. A. (2005). The effect of gender differences in primary school access, type, and quality on the decision to enroll in rural Pakistan. Economic Development and Cultural Change, 53(3), 685-710.

Muralidharan, K., \& Kremer, M. (2006). Public and private schools in rural India (Mimeo): Cambridge, MA: Harvard University Press.

Pakistan Bureau of Statistics. (2010). Pakistan social and living standards measurement (PSLM) survey 2008-09. Islamabad: Author.

Pakistan Bureau of Statistics. (2011). Pakistan social and living standards measurement (PSLM) survey, 2010-11. Islamabad: Author.

Pakistan, Ministry of Finance. (2010). Pakistan economic survey 2009-10. Islamabad: Author.

Psacharopoulos, G., Arieira, C. R., \& Mattson, R. (1997). Private education in a poor country: The case of urban Bolivia. Economics of Education Review, 16(4), 395-406.

Rehman, N. U., Khan, J., Tariq, M., \& Tasleem, S. (2010). Determinants of parents' choice in selection of private schools for their children in district Peshawar of Khyber Pakhtunkhwa province. European Journal of Scientific Research, 44(1), 140-151.

Rose, P. (2009). Nonstate provision of education: Evidence from Africa and Asia [Special issue]. Compare, 39(2), 127-134. 
Sathar, Z. A., \& Lloyd, C. B. (1994). Who gets primary schooling in Pakistan: Inequalities among and within families. Pakistan Development Review, 33(2), 103-134.

Siddiqui, S. (2007). Rethinking education in Pakistan: Perceptions, practices, and possibilities. Karachi, Pakistan: Paramount Publishing Enterprise.

Srivastava, P. (2006). Private schooling and mental models about girls' schooling in India. Compare, 36(4), 497-514.

Srivastava, P. (2007). Neither voice nor loyalty: School choice and the low-fee private sector in India (Occasional Paper No. 134). New York, NY: National Center for the Study of Privatization in Education.

Srivastava, P., \& Walford, G. (Eds.). (2007). Private schooling in less economically developed countries: Asian and African perspectives. Oxford, UK: Symposium.

Tooley, J. (2004). Private education and 'education for all'. Economic Affairs, 24(4), 4-7.

Tooley, J., \& Dixon, P. (2006). 'De facto' privatization of education and the poor: Implications of a study from sub-Saharan Africa and India. Compare, 36(4), 443-462.

Tooley, J., Dixon, P., \& Gomathi, S. V. (2007). Private schools and the millennium development goal of universal primary education: A census and comparative survey in Hyderabad, India. Oxford Review of Education, 33(5), 539-560.

Woodhead, M., Frost, M., James, Z. (2013). Does growth in private schooling contribute to Education for All? Evidence from a longitudinal, two-cohort study in Andhra Pradesh, India. International Journal of Educational Development, 33(1), 65-73. 


\section{Appendix}

\section{Supplementary tables and figures}

Table A1: Gender-disaggregated gross enrollment rates, 2009 (\%)

\begin{tabular}{lllllll}
\hline & \multicolumn{2}{c}{ Primary } & \multicolumn{2}{c}{ Secondary } & \multicolumn{2}{c}{ Tertiary } \\
\cline { 2 - 7 } Country & Males & Females & Males & Females & Males & Females \\
\hline Pakistan & 92.5 & 77.2 & 36.8 & 29.1 & 6.9 & 5.9 \\
India & 114.8 & 111.1 & 63.7 & 56.0 & 15.7 & 11.0 \\
Bangladesh & 93.2 & 97.2 & 39.9 & 44.8 & 10.0 & 5.6 \\
Sri Lanka & 96.7 & 97.1 & $\mathrm{Na}$ & $\mathrm{Na}$ & $\mathrm{Na}$ & $\mathrm{Na}$ \\
Maldives & 113.7 & 108.2 & 81.5 & 85.9 & $\mathrm{Na}$ & $\mathrm{Na}$ \\
Bhutan & 108.4 & 109.9 & 62.0 & 61.4 & 8.2 & 4.8 \\
\hline
\end{tabular}

Source: World Development Indicators, 2010.

Table A2: Patterns of enrollment and out-of-school children (5-18) in rural Pakistan (\%)

\begin{tabular}{lcccccc}
\hline Quintile & Enrolled & Never attended & Private & Public & Madrassa & Other \\
\hline Lowest & 49.7 & 50.3 & 14.7 & 82.7 & 1.5 & 1.1 \\
Males & 59.9 & 40.1 & 13.9 & 83.5 & 1.7 & 1.0 \\
Females & 36.6 & 63.4 & 16.5 & 81.0 & 1.3 & 1.2 \\
Quintile2 & 50.5 & 49.5 & 11.6 & 85.4 & 2.0 & 1.0 \\
Males & 60.0 & 40.0 & 11.3 & 85.6 & 2.3 & 0.8 \\
Females & 39.6 & 60.4 & 12.1 & 85.1 & 1.4 & 1.4 \\
Quintile3 & 58.1 & 41.9 & 13.8 & 83.7 & 1.3 & 1.1 \\
Males & 68.4 & 31.6 & 12.9 & 84.6 & 1.5 & 1.1 \\
Females & 46.0 & 54.0 & 15.6 & 82.2 & 1.0 & 1.2 \\
Quintile4 & 61.4 & 38.6 & 14.9 & 82.6 & 1.4 & 1.1 \\
Males & 70.2 & 29.8 & 14.5 & 83.2 & 1.3 & 1.0 \\
Females & 50.8 & 49.2 & 15.7 & 81.5 & 1.5 & 1.3 \\
Highest & 62.3 & 37.8 & 22.5 & 75.1 & 1.4 & 1.0 \\
Males & 69.2 & 30.8 & 22.3 & 75.3 & 1.5 & 0.9 \\
Females & 53.3 & 46.7 & 22.8 & 74.7 & 1.3 & 1.1 \\
\hline
\end{tabular}

Source: PSLM 2008/09. 
Table A3: Patterns of enrollment and out-of-school children (5-18) by gender and socioeconomic status (\%)

\begin{tabular}{lccccccc}
\hline & \multicolumn{2}{c}{ In school } & \multicolumn{2}{c}{ Out of school $^{*}$} & \multicolumn{4}{c}{ Type of school $^{* *}$} \\
\cline { 2 - 7 } Quintile & Enrolled & Never attended & Dropouts & Private & Govt. & Madrassas & Others \\
\hline Lowest & & & & & & & \\
Males & 56.0 & 34.3 & 9.6 & 8.6 & 88.2 & 0.0 & 3.2 \\
$\begin{array}{l}\text { Females } \\
\text { Second }\end{array}$ & 44.8 & 41.2 & 14.0 & 9.4 & 84.4 & 0.0 & 5.2 \\
Males & 74.1 & 13.2 & 12.6 & 15.8 & 78.7 & 0.0 & 4.7 \\
Females & 61.1 & 22.1 & 16.8 & 21.1 & 77.6 & 0.0 & 1.3 \\
Third & & & & & & & \\
Males & 70.4 & 16.4 & 13.2 & 22.3 & 75.0 & 0.0 & 2.7 \\
Females & 61.2 & 21.0 & 17.8 & 26.9 & 68.8 & 0.0 & 4.3 \\
Fourth & & & & & & & \\
Males & 77.3 & 7.1 & 15.6 & 23.9 & 73.4 & 0.0 & 2.7 \\
Females & 61.6 & 12.6 & 25.8 & 40.9 & 54.8 & 0.0 & 4.3 \\
Highest & & & & & & & \\
Males & 77.2 & 4.7 & 18.1 & 40.4 & 57.0 & 0.9 & 1.8 \\
Females & 81.8 & 8.0 & 10.2 & 47.7 & 48.6 & 0.9 & 2.7 \\
\hline
\end{tabular}

Note: ${ }^{*}=\%$ of children, ${ }^{* *}=\%$ of enrolled children.

Source: PERI School Choice Survey, 2011. 